\title{
Merger plans worry Japan's industrialists
}

[TOKYO] Japanese industrialists are voicing scepticism about the country's plans to restructure its science-related ministries, which otherwise have faced little public or political opposition. Many doubt whether the restructuring will increase efficiency as promised and thus genuinely improve the country's research base.

The government announced last November that it plans to merge its Science and Technology Agency (STA) with the education ministry by 2001 (see Nature 390, 327; 1997), as part of a series of reforms designed to improve the country's administration.

The hope is that the merger, which follows the 1996 Basic Science and Technology Law committing Japan in principle to increasing spending on science and technology by 50 per cent by the year 2001, will help to invigorate Japan's scientific research base.

But senior research managers at some of Japan's leading research-orientated companies are concerned that a culture clash between the traditional Ministry of Education, Science, Sports and Culture (Monbusho) and STA may delay reforms so much that the government is unable to deliver its promised efficiency gains.

Michiyuki Uenohara, for example, chairman of the NEC Research Institute, points out that Monbusho and STA have significantly different cultures. Monbusho has a reputation for being one of Japan's most conservative ministries, handing out research funds widely and evenly.

In contrast, STA prefers a more centralized, selective approach, and has been trying to introduce research assessment and other modern research management techniques to Japan. "There will be constant fighting," predicts Uenohara.

Susumu Nishimura, senior executive director with Banyu Tsukuba Research Institute, a leading Japanese pharmaceutical company, worries that a merger will be insufficient to produce the desired improvements unless the attitude of officials changes.

Such industrialists argue that the real need is to improve links between universities and industry, and to have more flexible research budgets, greater government transparency and less waste. They argue that the merger will not actually reduce waste, and may inadvertently increase bureaucracy.

For example, the ministry of international trade and industry and the ministry of agriculture, as well as Monbusho and STA, all support various kinds of genome-related research. "The overlap is often redundant," says Nishimura. But he points out that much overlap will remain even after the merger.

The additional funding brought about by the Basic Science and Technology Law, as well as various supplementary budgets, may be stimulating the economy and research in general terms, he says, but there is still too much waste.

Despite the new law, change in Japanese research has been slow, and collaboration between industry and universities is still much less common than in the United States, says Uenohara. His company, a world leader in research into carbon nanotubes and fullerenes, is unlikely in the near future to reverse its current policy of conducting most of its fundamental research in Princeton, New Jersey.

Other critics of the merger are concerned that the education ministry's resources are mainly dedicated to primary and secondary education, and that its higher education bureau is "very poorly managed". It also has a poor record in fostering links between universities and industry.

Supporters of the merger argue that it will strengthen science in higher education, and encourage collaboration between Mon- busho- and STA-run agencies - for example between Monbusho's Institute of Space and Astronautical Science and STA's National Space Development Agency.

The merger will, in principle, remove bureaucratic boundaries and make it easier for administrators to work more closely together, as they will all work for the same ministry, says one Monbusho official.

But many industrialists argue that integrating STA into Monbusho could lead to a situation in which inefficiency remains while research becomes a lower government priority, as there will no longer be an agency entirely dedicated to science and technology.

Senior Japanese academics have also expressed concern. They worry that the merger may lead to a centralized science administration that will damage the culture of basic research in Japan if it fails to encourage a more 'bottom-up' approach (see Nature 391, 431; 1998). The plan has still to be approved by Japan's parliament.

Richard Nathan

\section{Economy lifeline viewed as mixed blessing}

[TOKYO] Japan's largest-ever economic stimulus package, unveiled two weeks ago and intended to halt the deterioration in the country's economy, has met with mixed reactions from the scientific community.

Part of the extra money to be spent on public works which includes projects linked to environmental protection, energy, information and telecommunications - will go on improving research facilities at nationally run universities and institutes.

One beneficiary will be the University of Tokyo, which ran into difficulties last year when it failed to obtain government funding to acquire the land for its new campus in Kashiwa, Chiba prefecture (see Nature 392 , 429; 1998). The stimulus package will now allow the university to transfer its Institute of Solid State Physics to the new campus. Several projects will receive additional funding from the stimulus package as part of its commitment to promoting 'commercially applicable research'. For example, the Biomolecular Frontier Programme and the Brain Research Institute will receive a further $¥ 3.4$ billion (US\$26 million) and $¥ 5.3$ billion respectively towards the completion of new research buildings, and $¥ 18.7$ billion will go to work on the Japanese module of the International Space Station.

But many scientists remain worried that the hastily compiled package risks wasting money by investing heavily in expensive equipment and buildings without ensuring their efficient use.

A director of one research institute run by the Ministry of Education, Science, Sports and Culture says: "It seems that the construction, transportation and telecommunications ministries, as well as related industries, managed to win the money-grabbing game. There has been very little planning behind this."

His major concern is that, if the new stimulus package were to be followed by a sharp recession in a couple of years' time, universities and research institutes could be left with pristine facilities and state-of-the-art equipment, but no money to run them.

Almost half of the $¥ 16.65$ trillion package will be spent on public works projects proposed by national and local governments. Most of the public works funds will be spent on traditional projects such as reclamation and building highways, roads and bridges, but $¥ 1.5$ trillion will be invested in 'new types' of projects such as developing a fibre-optic communications network.

The heavy emphasis in the stimulus package on traditional public works is intended, it seems, to allow these areas to acquire what they failed to gain in the main 1998 budget that came into effect on 1 April.

This budget had originally been drawn up under new fiscal legislation, introduced last November, to cap major spending and reduce the national deficit. But the government has since amended the law to allow it to launch the economy-boosting package. Asako Saegusa 